\title{
Identification of Onosma visianii Roots Extract and Purified Shikonin Derivatives as Potential Acaricidal Agents against Tetranychus urticae
}

\author{
Stefania Sut ${ }^{1, \dagger}{ }^{\dagger}$ Roman Pavela ${ }^{2, \dagger}$, Vladislav Kolarčik ${ }^{3}$, Loredana Cappellacci ${ }^{4}$, \\ Riccardo Petrelli ${ }^{4}$, Filippo Maggi ${ }^{4, *}$, Stefano Dall'Acqua ${ }^{1, *}$ and Giovanni Benelli 5 \\ 1 Department of Pharmaceutical and Pharmacological Sciences, University of Padova, Via Marzolo, \\ 35121 Padova, Italy; stefania.sut@unipd.it \\ 2 Crop Research Institute, Drnovska 507, 161 06, Prague 6, Czech Republic; pavela@vurv.cz \\ 3 Department of Botany, Institute of Biology and Ecology, Faculty of Science, P.J. Šafárik University, \\ Mánesova 23, 04154 Košice, Slovakia; vladislav.kolarcik@upjs.sk \\ 4 School of Pharmacy, University of Camerino, Via Sant'Agostino 1, 62032 Camerino, Italy; \\ loredana.cappellacci@unicam.it (L.C.); riccardo.petrelli@unicam.it (R.P.) \\ 5 Department of Agriculture, Food and Environment, University of Pisa, via del Borghetto 80, \\ 56124 Pisa, Italy; benelli.giovanni@gmail.com \\ * Correspondence: filippo.maggi@unicam.it (F.M.); stefano.dallacqua@unipd.it (S.D.); \\ Tel.: +39-073-740-4506 (F.M.); +39-049-827-5344 (S.D.); Fax: +39-073-763-7345 (F.M.); +39-049-827-5336 (S.D.); \\ + These authors contributed equally to the work.
}

Received: 11 May 2017; Accepted: 14 June 2017; Published: 16 June 2017

\begin{abstract}
There is an increasing need for the discovery of reliable and eco-friendly pesticides and natural plant-derived products may play a crucial role as source of new active compounds. In this research, a lipophilic extract of Onosma visianii roots extract containing $12 \%$ of shikonin derivatives demonstrated significant toxicity and inhibition of oviposition against Tetranychus urticae mites. Extensive chromatographic separation allowed the isolation of 11 naphthoquinone derivatives that were identified by spectral techniques and were tested against Tetranychus urticae. All the isolated compounds presented effects against the considered mite and isobutylshikonin (1) and isovalerylshikonin (2) were the most active, being valuable model compounds for the study of new anti-mite agents.
\end{abstract}

Keywords: biopesticide; eco-friendly insecticide; Tetranychus urticae; Onosma visianii; shikonin derivatives

\section{Introduction}

There is an urgent need for the discovery of new compounds to be used as pest control agents because the synthetic pesticides currently marketed have harmful effects on human health and the environment. Notably, these products may also kill natural enemies, allowing an exponential increase of pest populations [1]. Therefore, there is a need to discover safe products with low risks for human health and environmental damage. In this framework, research on plant secondary metabolites offers new routes to explore in the search of alternatives to conventional pesticides causing no damage to the environment and non-target organisms [2-5].

The two-spotted spider mite T. urticae (Acari: Tetranychidae) is a polyphagous herbivore feeding on over 1100 species, including over 150 with economic value [6]. Thus, it represents a threat for greenhouse and field crops, with special reference to Solanaceae and Cucurbitaceae species, accounting for about $5 \%$ loss in agricultural productivity worldwide [7]. It has been reported that, owing to the global warming, the two-spotted spider mite's damages in agriculture are expected to increase dramatically in the future because the mite's development is strongly correlated with 
high temperatures [8]. An important hallmark of T. urticae is its quick capability to develop resistance to synthetic insecticides. Furthermore, some biological features such as high fecundity, fast development, and haplo-diploid sex determination make the two-spotted spider mite able to speed up its development of pesticide resistance [9].

Onosma visianii Clem, belonging to the Boraginaceae family, sect. Haplotricha Boiss., is a biennial herb occurring in steppic and rocky calcareous sites of Central and Southeastern Europe [10]. The plant is characterized by simple indumentum on green organs, composed of multicellular tubercles, with single setae on the top of tubercle and without asterosetules-short rays radially attached to the base of tubercle. The species is characterized by a sterile rosette of linear-lanceolate densely-setose leaves in first vegetation season; then usually a single reddish, erect, and branched stem with terminal cymes arises from the rosette in the second vegetation season. Flowers are sympetalous and heterochlamydeous, with short pedicels and pale-yellow tubular corolla. Fruits are minutely tuberculate beaked nutlets [11]. Roots are characterized by a showy red bark and are traditionally used to heal wounds and burns in several species of Onosma [12]. They are also used in folk veterinary medicine as a feed additive for cattle in Montenegro.

Several members of the Boraginaceae family, such as Lithospermum erythrorhizon Siebold \& Zucc., Alkanna tinctoria (L.) Tausch, Arnebia euchroma (Royle) I.M.Johnst., Echium plantagineum L. and O. heterophylla Griseb. have been extensively investigated from a phytochemical point of view [13]. A review has considered plants of the genus Onosma, showing the presence of several classes of secondary metabolites as aliphatic ketones, lipids, naphthazarins, alkaloids, phenolic compounds, flavones and naphthoquinones [14]. A recent paper considered O. panicolatum naphthoquinones for their anti-inflammatory potential [15], and some oligomers of alkannin and shikonins obtained from O. echioides were studied for wound-healing activity [16]. Specifically related to O. visianii, seven naphthoquinones were isolated and studied for antibacterial and cytotoxic activities with significant effects found [17].

Naphthoquinones are oxygen-derivatives of naphthalene, a class of plant secondary metabolites formed on a $\mathrm{C}_{6}-\mathrm{C}_{4}$ skeleton (molecular formula $\mathrm{C}_{10} \mathrm{H}_{6} \mathrm{O}_{2}$ ) originating from the shikimate pathway and widespread in several families, including Droseraceae, Juglandaceae, Nepenthaceae, Plumbaginaceae, and Boraginaceae, where they act as allelochemicals and defense against predators [13,18,19].

This group of secondary metabolites has attracted high research attention due to their notable pharmacological activities, which include antimicrobial, anticancer, wound healing, anti-inflammatory, and antithrombotic uses $[13,20]$. They have also been employed as pigments, dyes, cosmetics, and food additives [21]. The main examples are given by plumbagin, juglone, lawsone, alkannin, and shikonin and its derivatives, with the latter as the most important pigments used commercially [22].

It is worth noting that naphthoquinones are considered as promising candidates for the development of botanical pesticides. As an example, plumbagin and juglone showed important acaricidal and insecticidal effects $[20,23]$. To date, only a few naphthoquinones have been evaluated for acaricidal activity [24].

Here, the hexane extract of $O$. visianii roots was selected as a source of bioactive naphthoquinone to be studied against the two-spotted spider mite T. urticae. Firstly, the activity of O. visianii extract was tested on mortality and oviposition of T. urticae. Then, the activity of compounds 1-11 was also determined and for the most active derivatives (1-2), deeper investigations were performed allowing the observation of acute and chronic toxicity, as well as the oviposition inhibitory effects against the target mite species. The findings of this work provide new insights into the potential of O. visianii as a source of highly effective naphthoquinone derivatives as acaricides. 


\section{Results and Discussion}

\subsection{Bioactivity of Hexane Extract on T. urticae}

The application of the hexane extract from $O$. visianii roots with $12 \%$ of shikonin derivatives caused significant mortality of T. urticae adults (Table 1) as early as $24 \mathrm{~h}$ from application, with lethal doses causing 50\% $\left(\mathrm{LD}_{50}\right)$ and 90\% (LD $\left.\mathrm{LD}\right)$ inhibition of oviposition, estimated as 83.2 and $112.6 \mu \mathrm{g} \cdot \mathrm{cm}^{-2}$, respectively. However, the dose needed to kill 50\% of the adults decreased significantly as a function of time, and on day 5 from application, $L_{50}$ was more than 30 times lower $\left(2.6 \mu \mathrm{g} \cdot \mathrm{cm}^{-2}\right)$. The effect of the hexane extract on inhibition of oviposition by T. urticae females is shown in Table 1. The extract was found to inhibit oviposition, and the $\mathrm{LD}_{50}\left(\mathrm{LD}_{90}\right)$ was estimated as $2.4(43.5) \mu \mathrm{g} \cdot \mathrm{cm}^{-2}$.

Table 1. Activity and impact on Tetranychus urticae oviposition of the Onosma visianii root extract.

\begin{tabular}{|c|c|c|c|}
\hline Activity & $\mathrm{LD}_{50}\left(\mathrm{CI}_{95}\right)^{\mathrm{a}}$ & $\mathrm{LD}_{90}\left(\mathrm{CI}_{95}\right)^{\mathrm{a}}$ & $\mathrm{Chi}^{\mathrm{b}}$ \\
\hline Acute toxicity (tarsal test, after $24 \mathrm{~h}, \mu \mathrm{g} \cdot \mathrm{cm}^{-2}$ ) & $83.2(79.8-89.5)$ & $112.6(101.5-121.8)$ & 0.158 \\
\hline Chronic toxicity (tarsal test, after 5 days, $\mu \mathrm{g} \cdot \mathrm{cm}^{-3}$ ) & $2.6(1.7-3.5)$ & $9.4(6.2-15.5)$ & 0.634 \\
\hline Oviposition inhibition $\left(\mu \mathrm{g} \cdot \mathrm{cm}^{-3}\right)$ & $2.4(2.2-3.9)$ & $43.5(41.8-45.9)$ & 0.525 \\
\hline
\end{tabular}

\subsection{Isolation of Naphthoquinones and Structure Elucidation of Constituents}

Due to this effect, separation of the constituents of the extract was performed. By extensive chromatographic purification, compounds 1-11 were isolated and characterized by the means of spectral methods (Table 2). Among them, two structures (8 and 11) were revealed to be new natural products (Figure 1).

Compound 8 was isolated as a yellow solid. The HR-MS spectrum of compound 8 showed the presence of a pseudomolecular ion at $m / z 401.1940$, corresponding to the molecular formula of $\mathrm{C}_{23} \mathrm{H}_{28} \mathrm{O}_{6}$ (calculated $401.1964 \mathrm{Da}$ ). The compound presented a single HPLC peak and the ${ }^{1} \mathrm{H}-\mathrm{NMR}$ spectrum showed signals related to the aromatic part of the compound that was characterized by the presence of singlet at $\delta 7.32(\mathrm{H}-6 / 7), 6.60(\mathrm{H}-3)$, and two identical methoxy groups in positions 5 and 8 ( $\delta 3.96)$. The ester chain presents a triplet at $\delta 0.92(3 \mathrm{H}, \mathrm{t}, J=7.42)$, and from a correlation spectroscopy (COSY) spectrum the spin system was deduced, and was from $\mathrm{H}-4^{\prime \prime}\left(\mathrm{CH}_{3}\right.$ at $\left.\delta 0.92\right)$ to $\mathrm{H}-3^{\prime \prime}\left(\delta 2.25, \mathrm{CH}_{2}\right)$ from this, later to $\mathrm{H}-2^{\prime \prime}(\delta 2.42, \mathrm{CH})$, and from this later to the methyl group $\mathrm{H}-5^{\prime \prime}$ at $\delta 1.15(3 \mathrm{H}, \mathrm{d}, J=7.02)$. The NMR data support the presence of 2-(1-hydroxy-4-methylpent-3-en-1-yl)5,8-dimethoxynaphthalene-1,4-dione moiety with ester substituents at $\mathrm{OH}$ in position $1^{\prime}$. In particular, the heteronuclear multiple bond coherence (HMBC) correlations from $\mathrm{CH}_{3}-5^{\prime \prime}$ with carbon resonances at $\delta 44.8\left(\mathrm{C}-3^{\prime \prime}\right), 42.4\left(\mathrm{C}-2^{\prime \prime}\right)$, and $175.0\left(\mathrm{C}-1^{\prime \prime}\right)$ support the presence of a residue of 2-methylbutanoate. Diagnostic HMBC correlations observed from $\mathrm{H}-2^{\prime \prime \prime}$ with carbon resonance at $\delta 170.0\left(\mathrm{C}-1^{\prime \prime \prime}\right)$ and 23.9 $\left(\mathrm{C}-4^{\prime \prime \prime} / 5^{\prime \prime \prime}\right)$ support the presence of a 3-methylbutanoate residue. Thus, compound 8 was identified as 1-(5,8-dimethoxy-1,4-dioxo-1,4-dihydronaphthalen-2-yl)-4-methylpent-3-en-1-yl 2-methylbutanoate. 
<smiles>CC(C)=CCC(OC(=O)CC(C)C)C1=CC(=O)c2c(O)ccc(O)c2C1=O</smiles><smiles>CC(C)=CCC(OC(=O)C(C)C)C1C(=O)C(=O)c2c(O)ccc(O)c2C1=O</smiles><smiles>COc1ccc(OC)c2c1C(=O)C=C(C(CC=C(C)C)OC(C)=O)C2=O</smiles><smiles>CC(=O)OC(CC=C(C)C)C1=CC(=O)c2c(O)ccc(O)c2C1=O</smiles><smiles>[R]CC(C)C(=O)O</smiles>

3<smiles>CC(C)=CCC(OC(=O)CC(C)(C)O)C1=CC(=O)c2c(O)ccc(O)c2C1=O</smiles><smiles>COc1ccc(OC)c2c1C(=O)C(=O)C(C(CC=C(C)C)OC(=O)C(C)C)C2=O</smiles><smiles>COc1ccc(OC)c2c1C(=O)C(=O)C=C(CCC=C(C)C)C2=O</smiles><smiles>CC(C)=CCC(OC(=O)C=C(C)C)C1=CC(=O)c2c(O)ccc(O)c2C1=O</smiles>

5<smiles>CCC(=O)OC(CC=C(C)C)C1=CC(=O)c2c(O)ccc(O)c2C1=O</smiles><smiles>COc1ccc(OC)c2c1C(=O)C=C(C/C=C/C(C)(C)O)C2=O</smiles>

11

Figure 1. Structure of the eleven naphthoquinones isolated from O. visianii roots.

Compound 11 was isolated as a yellow solid. The HR-MS spectrum of compound $\mathbf{1 1}$ showed the presence of a pseudomolecular ion at $m / z 317.3520$ corresponding to molecular formula of $\mathrm{C}_{18} \mathrm{H}_{20} \mathrm{O}_{5}$ (calculated $317.3563 \mathrm{Da}$ ). The ${ }^{1} \mathrm{H}-\mathrm{NMR}$ spectrum was characterized by the presence of a series of signals ascribable to a naphthoquinone moiety, namely the singlets at $\delta 7.31(2 \mathrm{H}, \mathrm{s}), 7.21(1 \mathrm{H}, \mathrm{s})$, partially overlapped to chloroform signal, a doublet at $\delta 5.80(1 \mathrm{H}, \mathrm{d}, J=15.85)$, and a doublet of triplets at $\delta 5.73(1 \mathrm{H}, \mathrm{dt}, J=15.85 ; 5.68)$ that support the presence of a trans olefin linked to a $\mathrm{CH}_{2}$, a singlet at $\delta$ $3.95(6 \mathrm{H}, s)$ supporting the presence of two identical methoxy groups a broad doublet at $\delta 3.25(2 \mathrm{H}$, $\mathrm{d}, J=5.68)$, and two aliphatic singlets at $\delta 1.35$ and 1.27 (3H each, s) suggesting the presence of two quaternary methyl groups. The heteronuclear single quantum correlation-distortionless enhancement 
by polarization transfer (HSQC-DEPT) experiment allowed the assignment of the chemical shift of the non-quaternary carbon positions, and revealed the presence in the molecule of four different $\mathrm{sp}^{2} \mathrm{CH}$, one $\mathrm{sp}^{3} \mathrm{CH}_{2}$, and three $\mathrm{CH}_{3}$. From the comparison of $\mathrm{H}$, HSQC-DEPT and HMBC the correlations between $\mathrm{H}$ and $\mathrm{C}$ were deduced and the structure of the compound was assigned. Namely the aromatic portion was assigned to a 1 substituted 5,8-dimethoxynaphthalene-1,4-dione. Diagnostic HMBC correlations were observed from H-6/7 ( $\delta 7.31)$ with carbon resonances at $\delta 153.05(\mathrm{C}-5 / 8)$, 121.05 (C-6/7), and 100.25 (C-9/10). Further HMBC correlations were observed from H-3 ( $\delta 7.21)$ with carbon resonances at $\delta 184.7$ (C-1) supporting the presence of keto group, and with a quaternary carbon at $\delta 148.3(\mathrm{C}-2)$, suggesting the presence of a substituent in position 2 . Considering the signals ascribable to a side chain, HMBC correlations were observed from $\mathrm{H}-1^{\prime}$ with $\mathrm{C}-2$ and $\mathrm{C}-1$ ( $\delta$ 184.7), supporting the linkage with the naphthalene moiety at position 2 . Further diagnostic HMBC signals were also observed from $\mathrm{H}-1^{\prime}$ with $\mathrm{C}-2^{\prime}(\delta 121.8)$ and $\mathrm{C}-3^{\prime}(\delta 142.1)$, supporting the presence of a double bond in the side chain. COSY correlation revealed the scalar coupling between $\mathrm{H}-1^{\prime}$ and $\mathrm{H}-2^{\prime}$, and from this later to $\mathrm{H}-3^{\prime}$. The coupling constant of $\mathrm{H}-3^{\prime}(J=15.85)$ support a trans geometry for the double bond. A linkage at position $3^{\prime}$ of a hydroxyl-isopropyl moiety was deduced from the HMBC correlations observed from $\mathrm{H}-3^{\prime}$ with $\mathrm{C}-4^{\prime}(\delta 69.9), \mathrm{C}-5^{\prime}$ ( $\left.\delta 30.43\right)$, and C-4'. Also, NOESY correlation from H-6 $6^{\prime}(\delta 1.27)$ and $\mathrm{H}-2^{\prime}$ confirm the structure of the side chain as a (E)-2-(4-hydroxy-4-methylpent-2-en-1-yl) moiety. Thus, the structure of the compound 11 was assigned to (E)-2-(4-hydroxy-4-methylpent-2-en-1-yl)-5,8-dimethoxynaphthalene-1,4-dione. The NMR assignments and the structures of the new isolated compounds are reported in Table 2 and Figure 2, respectively.

Table 2. NMR assignments for the new isolated compounds.

\begin{tabular}{|c|c|c|c|c|}
\hline \multirow{2}{*}{ Position } & \multicolumn{2}{|l|}{8} & \multicolumn{2}{|l|}{11} \\
\hline & $\delta_{H}$ & $\delta_{C}$ & $\delta_{H}$ & $\delta_{C}$ \\
\hline 1 & - & 184.7 & - & 182.8 \\
\hline 2 & - & 148.3 & - & 147.5 \\
\hline 3 & $7.21 \mathrm{~s}$ & 118.9 & $6.60 \mathrm{t}, J=1.22$ & 133.6 \\
\hline 4 & - & 184.7 & - & 182.8 \\
\hline 5 & - & 153.1 & - & 153.4 \\
\hline 6 & $7.31 \mathrm{~s}$ & 121.1 & $7.32 \mathrm{~s}$ & 120.8 \\
\hline 7 & $7.31 \mathrm{~s}$ & 121.1 & $7.32 \mathrm{~s}$ & 120.8 \\
\hline 8 & - & 153.1 & - & 153.4 \\
\hline 9 & - & 121.2 & - & 120.9 \\
\hline 10 & - & 121.2 & - & 120.9 \\
\hline $\mathrm{OCH}_{3}$ & $3.95 \mathrm{~s}$ & 57.3 & $3.96 \mathrm{~s}$ & 57.8 \\
\hline $\mathbf{1}^{\prime}$ & $3.25 \mathrm{~d}, J=5.68$ & 32.0 & $5.94 \mathrm{~m}$ & 70.0 \\
\hline $2^{\prime}$ & $5.73 \mathrm{dt}, J=15.85 ; 5.68$ & 121.8 & $2.45-2.60 \mathrm{~m}$ & 31.1 \\
\hline $3^{\prime}$ & $5.80 \mathrm{~d}, J=15.85$ & 142.1 & $5.11 \mathrm{~m}$ & 117.1 \\
\hline $4^{\prime}$ & - & 69.9 & - & 134.9 \\
\hline $5^{\prime}$ & $1.35 \mathrm{~s}$ & 30.4 & 1.57 brs & 14.9 \\
\hline $6^{\prime}$ & $1.27 \mathrm{~s}$ & 26.9 & $1.64 \mathrm{brs}$ & 27.1 \\
\hline $\mathbf{1}^{\prime \prime}$ & & & - & 175.0 \\
\hline $2^{\prime \prime}$ & & & $2.42 \mathrm{~m}$ & 42.4 \\
\hline $3^{\prime \prime}$ & & & $2.25 \mathrm{~m}$ & 44.8 \\
\hline $4^{\prime \prime}$ & & & $0.92 \mathrm{t}, J=7.32$ & 12.7 \\
\hline $5^{\prime \prime}$ & & & $1.15 \mathrm{~d}, J=7.02$ & 17.6 \\
\hline $1^{\prime \prime \prime}$ & & & - & 170.0 \\
\hline $2^{\prime \prime \prime}$ & & & $2.28 \mathrm{~m}$ & 44.9 \\
\hline $3^{\prime \prime \prime}$ & & & $2.14 \mathrm{~m}$ & 27.1 \\
\hline $4^{\prime \prime \prime}$ & & & $0.96 \mathrm{~d}, J=6.71$ & 23.9 \\
\hline $5^{\prime \prime \prime}$ & & & $0.97 \mathrm{~d}, J=6.71$ & 23.9 \\
\hline
\end{tabular}

Note: Spectra were acquired at 40,014 MHz for ${ }^{1} \mathrm{H}$ and $100 \mathrm{MHz}$ for ${ }^{13} \mathrm{C}$ in $\mathrm{CDCl}_{3}$ using TMS as internal reference. The chemical shifts $(\delta)$ are expressed in ppm. All coupling constants $(J)$ are expressed in Hz. 
<smiles>COc1ccc(OC)c2c1C(=O)C=C(C/C=C/C(C)(C)O)C2=O</smiles>

11<smiles>[R]C(CC=C(C)C)C1=CC(=O)c2c(OC)ccc(OC)c2C1=O</smiles>

8

Figure 2. Structure of the new isolated compounds.

\subsection{Activity of Isolated Compounds against T. urticae}

The eleven shikonin derivatives isolated from the root hexane extract (Figure 1) were tested at a dose of $15 \mu \mathrm{g} \cdot \mathrm{cm}^{-2}$, corresponding to the dose of shikonin administered in the test of the crude extract showing $\mathrm{LD}_{50}$ and $\mathrm{LD}_{90}$. Compounds 1 and $\mathbf{2}$ caused $100 \%$ mortality of the adults and nymphs on day 5 from application (Table 3), and present a value larger than $94 \%$ for oviposition inhibition. The other derivatives present significant effects. Despite the relatively low number of isolated compounds, some preliminary structure activity relationships may be observed. Indeed, methoxylation of position 5 and 8 caused significant loss of activity, suggesting an important role of the two $p$-hydroxy groups (C-5 and C-8) for the activity.

Table 3. Activity and impact on Tetranychus urticae oviposition of shikonin derivatives from root of Onosma visianii.

\begin{tabular}{|c|c|c|c|c|c|c|}
\hline \multirow{3}{*}{$\begin{array}{c}\text { Compound } \\
\text { No. }\end{array}$} & \multicolumn{4}{|c|}{ Mortality $^{a}(\%)$} & \multirow{2}{*}{\multicolumn{2}{|c|}{ Inhibition of Oviposition ${ }^{a}(\%)$}} \\
\hline & \multicolumn{2}{|c|}{ Adults } & \multicolumn{2}{|c|}{ Nymphs } & & \\
\hline & 2nd Day & 5th Day & 2nd Day & 5th Day & 2nd Day & 5th Day \\
\hline 1 & $48.1 \pm 5.3$ & $100.0 \pm 0.0$ & $28.2 \pm 5.1$ & $100.0 \pm 0.0$ & $78.7 \pm 8.7$ & $94.5 \pm 8.6$ \\
\hline 2 & $84.1 \pm 6.9$ & $100.0 \pm 0.0$ & $84.6 \pm 5.8$ & $100.0 \pm 0.0$ & $90.3 \pm 3.3$ & $97.4 \pm 3.5$ \\
\hline 3 & $80.1 \pm 7.2$ & $91.7 \pm 5.8$ & $58.9 \pm 7.4$ & $74.3 \pm 5.8$ & $81.8 \pm 5.8$ & $94.8 \pm 7.1$ \\
\hline 4 & $32.1 \pm 3.9$ & $62.5 \pm 5.2$ & $58.8 \pm 4.6$ & $67.9 \pm 4.8$ & $25.4 \pm 5.4$ & $52.8 \pm 4.9$ \\
\hline 5 & $20.1 \pm 3.5$ & $41.7 \pm 2.5$ & $57.9 \pm 6.2$ & $80.7 \pm 5.3$ & $0.8 \pm 0.3$ & $33.1 \pm 9.1$ \\
\hline 6 & $68.2 \pm 5.3$ & $89.7 \pm 5.2$ & $69.2 \pm 7.1$ & $80.7 \pm 5.4$ & $64.8 \pm 4.8$ & $91.5 \pm 9.5$ \\
\hline 7 & $52.3 \pm 4.8$ & $58.4 \pm 4.3$ & $84.6 \pm 5.3$ & $87.1 \pm 7.9$ & $7.2 \pm 2.7$ & $48.7 \pm 5.7$ \\
\hline 8 & $40.3 \pm 3.7$ & $50.1 \pm 3.9$ & $67.2 \pm 3.7$ & $69.2 \pm 4.8$ & $18.1 \pm 8.2$ & $50.1 \pm 4.2$ \\
\hline 9 & $68.2 \pm 7.9$ & $79.9 \pm 3.8$ & $74.3 \pm 5.8$ & $75.3 \pm 5.5$ & $66.1 \pm 6.1$ & $80.7 \pm 6.9$ \\
\hline 10 & $20.6 \pm 3.9$ & $41.7 \pm 3.9$ & $61.5 \pm 3.9$ & $68.8 \pm 7.2$ & $9.1 \pm 1.5$ & $49.5 \pm 7.2$ \\
\hline 11 & $44.4 \pm 4.7$ & $66.7 \pm 4.8$ & $35.8 \pm 7.2$ & $36.4 \pm 4.6$ & $34.5 \pm 4.5$ & $54.7 \pm 8.5$ \\
\hline
\end{tabular}

${ }^{a}$ Mortality (\% after correction by Abbott) and oviposition inhibition values are followed by standard deviations (S.D.); all compounds were at $15 \mu \mathrm{g} \cdot \mathrm{cm}^{-2}$; the two most effective compounds are highlighted in bold.

Based on analyses of the isolated compounds, isobutyrylshikonin (1) and isovalerylshikonin (2) were found to provide the highest efficacy. Lethal doses for day 5 from application (Tables 4 and 5) were determined for these compounds in subsequent acaricidal tests. Isovalerylshikonin was found to provide a significantly higher efficacy, with an $\mathrm{LD}_{50}\left(\mathrm{LD}_{90}\right)$ estimated as 1.06 (4.15) and 1.65 (6.67) $\mu \mathrm{g} \cdot \mathrm{cm}^{-2}$ for adults and nymphs, respectively (Table 5). These doses were significantly lower compared with isobutyrylshikonin, whose $\mathrm{LD}_{50}\left(\mathrm{LD}_{90}\right)$ values were estimated as 2.69 (15.55) and 6.65 (13.16) $\mu \mathrm{g} \cdot \mathrm{cm}^{-2}$ for adults and nymphs, respectively (Table 4 ). 
Table 4. Activity of isobutyrylshikonin (1) on Tetranychus urticae mites.

\begin{tabular}{|c|c|c|c|c|c|c|c|c|c|c|}
\hline \multirow{2}{*}{$\begin{array}{c}\text { Dose } \\
\left(\mu \mathrm{g} \cdot \mathrm{cm}^{-2}\right)\end{array}$} & \multicolumn{5}{|c|}{ Adults } & \multicolumn{5}{|c|}{ Nymphs } \\
\hline & 2nd Day ${ }^{a}$ & 5th Day ${ }^{a}$ & $\begin{array}{c}\mathrm{LD}_{50} \mathrm{~b} \\
\left(\mathrm{CI}_{95}\right)\end{array}$ & $\begin{array}{l}\mathrm{LD}_{90} \mathrm{~b} \\
\left(\mathrm{CI}_{95}\right)\end{array}$ & $\mathrm{Chi}^{\mathrm{c}}$ & 2nd Day ${ }^{a}$ & 5th Day ${ }^{a}$ & $\begin{array}{c}\mathrm{LD}_{50} \mathrm{~b} \\
\left(\mathrm{CI}_{95}\right)\end{array}$ & $\begin{array}{c}\mathrm{LD}_{90} \mathrm{~b} \\
\left(\mathrm{CI}_{95}\right)\end{array}$ & $\mathrm{Chi}^{\mathrm{c}}$ \\
\hline 6.8 & $24.1 \pm 7.2$ & $67.8 \pm 5.9$ & & & & $12.9 \pm 3.2$ & $33.6 \pm 7.2$ & & & \\
\hline 3.4 & $31.1 \pm 5.9$ & $57.1 \pm 3.9$ & 2.69 & 15.55 & & $15.1 \pm 4.4$ & $21.3 \pm 5.9$ & 6.65 & 13.16 & \\
\hline 1.7 & $6.9 \pm 3.8$ & $35.6 \pm 4.9$ & $(2.25-3.17)$ & (11.67-18.93) & 5.362 & $2.1 \pm 0.8$ & $3.3 \pm 2.1$ & (3.95-8.12) & (12.97-15.89) & 2.555 \\
\hline
\end{tabular}

${ }^{a}$ Mortality (\% after correction by Abbott) of adults or nymphs \pm standard deviation (S.D.); ${ }^{b} \mathrm{LD}_{50}\left(\mathrm{LD}_{90}\right)=$ dose in $\mu \mathrm{g} \cdot \mathrm{cm}^{-2}$ causing $50 \%(90 \%)$ mortality of adults and nymphs T. urticae; $\mathrm{CI}_{95}=95 \%$ confidence intervals, the activity is considered significantly different when the $95 \% \mathrm{CI}$ fail to overlap; ${ }^{\mathrm{c}}$ Chi-square value, not significant at $p>0.05$ level.

Table 5. Activity of isovalerylshikonin against Tetranychus urticae mites.

\begin{tabular}{|c|c|c|c|c|c|c|c|c|c|c|}
\hline \multirow{2}{*}{$\begin{array}{c}\text { Dose } \\
\left(\mu \mathrm{g} \cdot \mathrm{cm}^{-2}\right)\end{array}$} & \multicolumn{5}{|c|}{ Adults } & \multicolumn{5}{|c|}{ Nymphs } \\
\hline & 2nd Day ${ }^{a}$ & 5th Day ${ }^{a}$ & $\begin{array}{l}\mathrm{LD}_{50} \mathrm{~b} \\
\left(\mathrm{CI}_{95}\right)\end{array}$ & $\begin{array}{l}\mathrm{LD}_{90} \mathrm{~b} \\
\left(\mathrm{CI}_{95}\right)\end{array}$ & $\mathrm{Chi}^{\mathrm{c}}$ & 2nd Day ${ }^{a}$ & 5th Day ${ }^{a}$ & $\begin{array}{l}\mathrm{LD}_{50}{ }^{\mathrm{b}} \\
\left(\mathrm{CI}_{95}\right)\end{array}$ & $\begin{array}{l}\mathrm{LD}_{90} \mathrm{~b} \\
\left(\mathrm{CI}_{95}\right)\end{array}$ & $\mathrm{Chi}^{\mathrm{c}}$ \\
\hline 13.5 & $75.8 \pm 5.8$ & $100.0 \pm 0.0$ & & & & $20.8 \pm 7.5$ & $100.0 \pm 0.0$ & & & \\
\hline 6.8 & $44.9 \pm 5.2$ & $96.4 \pm 2.6$ & & & & $12.9 \pm 3.2$ & $94.4 \pm 3.5$ & & & \\
\hline 3.4 & $24.2 \pm 3.9$ & $82.1 \pm 6.2$ & 1.06 & 4.15 & & $15.1 \pm 4.4$ & $61.8 \pm 3.2$ & & & \\
\hline 1.7 & $20.7 \pm 5.1$ & $71.4 \pm 5.5$ & $(0.89-1.26)$ & $(3.43-5.32)$ & 3.121 & $2.1 \pm 0.8$ & $48.7 \pm 2.1$ & $(0.61-2.82)$ & (5.98-8.16) & 1.292 \\
\hline 0.8 & $1.1 \pm 0.1$ & $39.2 \pm 4.9$ & & & & $0.0 \pm 0.0$ & $32.2 \pm 2.5$ & & & \\
\hline Control & $9.6 \pm 0.2$ & $9.6 \pm 0.2$ & & & & $16.6 \pm 3.3$ & $18.5 \pm 1.3$ & & & \\
\hline
\end{tabular}

${ }^{a}$ Mortality (\% after correction by Abbott) of adults or nymphs \pm standard deviation (S.D.); ${ }^{b} \mathrm{LD}_{50}$ and $\mathrm{LD}_{90}=$ dose in $\mu \mathrm{g} \cdot \mathrm{cm}^{-2}$ causing $50 \%$ and $90 \%$ mortality of adults and nymphs T. urticae; $\mathrm{CI}_{95}=95 \%$ confidence intervals, the activity is considered significantly different when the $95 \% \mathrm{CI}$ fail to overlap; ${ }^{\mathrm{C}}$ Chi-square value, not significant at $p>0.05$ level.

Also, isovalerylshikonin provided a significantly higher inhibition of oviposition $\left(\mathrm{ED}_{50}\right.$ $\left.\left(\mathrm{ED}_{90}\right)=1.15(2.75) \mu \mathrm{g} \cdot \mathrm{cm}^{-2}\right)$ compared with isobutyrylshikonin, whose $\mathrm{ED}_{50}\left(\mathrm{ED}_{90}\right)$ was estimated as $2.71(9.31) \mu \mathrm{g} \cdot \mathrm{cm}^{-2}$ (Table 6). In addition, both compounds showed ovicidal effects on the eggs of T. urticae (Table 7). However, these tests determined a more significant ovicidal effect for isovalerylshikonin $\left(\mathrm{ED}_{50}\left(\mathrm{ED}_{90}\right)=2.1(5.4) \mu \mathrm{g} \cdot \mathrm{cm}^{-2}\right)$ compared with isobutyrylshikonin $\left(\mathrm{ED}_{50}\right.$ $\left.\left(E D_{90}\right)=9.7(60.6) \mu \mathrm{g} \cdot \mathrm{cm}^{-2}\right)$. Thus, as indicated by all the results, a significantly higher acaricidal efficacy was shown by the isolated naphthoquinone isovalerylshikonin.

Table 6. Oviposition inhibition activity of isobutyrylshikonin and isovalerylshikonin on Tetranychus urticae females.

\begin{tabular}{|c|c|c|c|c|c|c|c|c|c|c|}
\hline \multirow[b]{2}{*}{$\begin{array}{c}\text { Dose } \\
\left(\mu \mathrm{g} \cdot \mathrm{cm}^{-2}\right)\end{array}$} & \multicolumn{5}{|c|}{ Isobutyrylshikonin } & \multicolumn{5}{|c|}{ Isovalerylshikonin } \\
\hline & $\begin{array}{c}\text { Eggs/ } \\
\text { Female } \pm \\
\text { SD }^{\text {a }}\end{array}$ & $\begin{array}{l}\text { Inhibition } \\
\text { Oviposition } \\
(\% \pm \mathrm{SD})^{b}\end{array}$ & $\begin{array}{c}\mathrm{ED}_{50} \\
\left(\mathrm{CI}_{95}\right)^{\mathrm{c}}\end{array}$ & $\begin{array}{c}\mathrm{ED}_{90} \\
\left(\mathrm{CI}_{95}\right)^{\mathrm{c}}\end{array}$ & $\mathrm{Chi}^{\mathrm{d}}$ & $\begin{array}{c}\text { Eggs/ } \\
\text { Female } \pm \\
\text { SD }^{\text {a }}\end{array}$ & $\begin{array}{l}\text { Inhibition } \\
\text { Oviposition } \\
(\% \pm S D)^{b}\end{array}$ & $\begin{array}{c}\mathrm{ED}_{50} \\
\left(\mathrm{CI}_{95}\right)^{\mathrm{c}}\end{array}$ & $\begin{array}{c}\mathrm{ED}_{90} \\
\left(\mathrm{CI}_{95}\right)^{\mathrm{c}}\end{array}$ & $\mathrm{Chi}^{\mathrm{d}}$ \\
\hline 13.5 & $2.6 \pm 0.3$ & $91.1 \pm 3.2$ & & & & $0.3 \pm 0.1$ & $98.8 \pm 2.1$ & & & \\
\hline 6.8 & $4.3 \pm 1.1$ & $85.9 \pm 5.5$ & & & & $0.9 \pm 0.2$ & $97.0 \pm 3.5$ & & & \\
\hline 3.4 & $11.2 \pm 0.9$ & $62.7 \pm 4.3$ & 2.71 & 9.31 & 2524 & $2.5 \pm 0.8$ & $91.7 \pm 2.8$ & 1.15 & 2.75 & 2523 \\
\hline Control & $30.1 \pm 4.5$ & - & & & & $30.1 \pm 4.5$ & - & & & \\
\hline
\end{tabular}

${ }^{a}$ Average number of eggs laid per female \pm standard deviation (S.D.); ${ }^{b}$ Mean inhibition of oviposition (in \%) in comparison with the control \pm standard deviation; ${ }^{c}$ Effective dose $\mathrm{ED}_{50}\left(\mathrm{ED}_{90}\right)$ in $\mu \mathrm{g} \cdot \mathrm{cm}^{-2}$ causing $50 \%(90 \%)$ inhibition of egg laying by females T. urticae, compared with untreated control; $\mathrm{CI}_{95}=95 \%$ confidence intervals, the activity is considered significantly different when the $95 \% \mathrm{CI}$ fail to overlap; ${ }^{\mathrm{d}}$ Chi-square value, not significant at $p>0.05$ level. 
Table 7. Ovicidal activity of isobutyrylshikonin and isovalerylshikonin against Tetranychus urticae.

\begin{tabular}{|c|c|c|c|c|c|c|c|c|}
\hline \multirow{2}{*}{$\begin{array}{c}\text { Dose } \\
\mu \mathrm{g} \cdot \mathrm{cm}^{-2}\end{array}$} & \multicolumn{4}{|c|}{ Isobutyrylshikonin } & \multicolumn{4}{|c|}{ Isovalerylshikonin } \\
\hline & $\begin{array}{l}\text { Mortality of } \\
\text { Eggs (\%) }{ }^{\text {a }}\end{array}$ & $\begin{array}{l}\mathrm{ED}_{50} \mathrm{~b} \\
\left(\mathrm{CI}_{95}\right)\end{array}$ & $\begin{array}{l}\mathrm{ED}_{90} \mathrm{~b} \\
\left(\mathrm{CI}_{95}\right)\end{array}$ & $\mathrm{Chi}^{\mathrm{c}}$ & $\begin{array}{l}\text { Mortality of } \\
\text { Eggs }(\%)^{a}\end{array}$ & $\begin{array}{l}\mathrm{ED}_{50} \mathrm{~b} \\
\left(\mathrm{CI}_{95}\right)\end{array}$ & $\begin{array}{l}\mathrm{ED}_{90} \mathrm{~b} \\
\left(\mathrm{CI}_{95}\right)\end{array}$ & $\mathrm{Chi}^{\mathrm{c}}$ \\
\hline 13.5 & $58.9 \pm 6.5$ & & & & $100.0 \pm 0.0$ & & & \\
\hline 6.8 & $43.3 \pm 5.5$ & & & & $95.6 \pm 7.6$ & & & \\
\hline 3.4 & $18.6 \pm 3.9$ & 9.7 & 60.6 & & $70.7 \pm 3.8$ & 2.1 & 5.4 & \\
\hline 1.7 & $10.5 \pm 3.6$ & (7.8-12.8) & (58.9-92.2) & 1.546 & $42.3 \pm 5.2$ & $(1.7-2.3)$ & $(4.5-7.6)$ & $1.4 / 8$ \\
\hline 0.8 & $5.3 \pm 0.8$ & & & & $27.3 \pm 5.9$ & & & \\
\hline Control & $1.2 \pm 0.2$ & & & & $1.2 \pm 0.2$ & & & \\
\hline
\end{tabular}

${ }^{\text {a }}$ The average mortality (in \%) of eggs after treatment with the compounds isobutyrylshikonin and isovalerylshikonin \pm standard deviation (S.D.); ${ }^{\mathrm{b}}$ Effective dose $\mathrm{ED}_{50}\left(\mathrm{ED}_{90}\right)$ in $\mu \mathrm{g} \cdot \mathrm{cm}^{-2}$ causing $50 \%(90 \%)$ mortality of eggs of T. urticae, $\mathrm{CI}_{95}=95 \%$ confidence intervals, extract activity is considered significantly different when the $95 \% \mathrm{CI}$ fail to overlap;

${ }^{\mathrm{C}}$ Chi-square value, not significant at $p>0.05$ level.

\section{Discussion}

The activity of quinone-containing compounds against mites can be related to the generation of reactive oxygen species [25], inhibition of mitochondrial respiration [26,27], and DNA intercalation and breakdown. Some shikonins were also active against the stored product pests, Acanthoscelides obtectus and Epilachna varivestis [28]. Alkannin, the racemic mixture alkannin/shikonin, and acetylated shikonin derivatives have been proved as effective on larvae of the West Nile virus vector Culex pipiens [29]. Lawsone synthetic derivatives were highly effective against susceptible and resistant strains of T. urticae and Bemisia tabaci [30]. 1,4-Naphthoquinone, juglone, 2-methoxy-1,4-naphthoquinone and plumbagin showed antifeedant effects against the cabbage looper, Trichoplusia ni, that were higher than those of neem-based products [19]. Plumbagin showed toxicity against the two-spotted spider mite T. urticae, the aphids Myzus persicae and Illinoia liriodendra, and the house fly Musca domestica [31]. Acequinocyl, a synthetic compound related to the natural naphthoquinone plumbagin marketed in 1999 [32], is a potent inhibitor of several species of agricultural mites with low effects on beneficial mites, low mammalian toxicity, and short persistence in the environment [33]. The synthetic 2,3-dichloro-1,4-naphthoquinone is registered as an agricultural fungicide that is highly effective against plant pathogens belonging to the genus Colletotrichum [34].

In the present work, the remarkable acaricidal effects of $O$. visianii root extracts and isolated shikonin derivatives were reported for the first time. The total amount of shikonin derivatives was measured by ${ }^{1} \mathrm{H}-\mathrm{NMR}$ analysis and was $12 \%(w / w)$ of the dried hexane extract. The activity of the isolated compounds showed similar effects to those observed using the extract. For this reason and for the previous literature report indicating the bioactivity of naphthoquinones, we considered such constituents as the possible active compounds against T. urticae. Isolation of compounds and structure elucidation revealed a series of six shikonin esters with hydroxyl and methoxy groups in C5 and C8 position. The observed bioactivity may be in part related to the lipophilicity of these compounds, which allows passage through the insect cuticle and enter into individual cells where they interfere with molting and other physiological processes [2,6]. Our study focused on compounds $\mathbf{1}$ and 2, revealing significant effect.

The acaricidal effects of naphthoquinones are due to their capacity to act as potent inhibitors of electron transport [35], as uncouplers of oxidative phosphorylation [36], as DNA intercalating and alkylating agents, and as producers of reactive oxygen radicals [37]. With regard to the latter, the ability of naphthoquinones to generate reactive oxygen species enhances the feeding deterring effects [25], thus playing a pivotal role in the protection of plants against pathogens $[18,19]$. Also in our experiments on derivatives, the presence of free hydroxyl groups was important for the observed bioactivity. In fact, the derivatives with methoxylation in position 5 and 8 were less active than the corresponding non-substituted compounds.

All the compounds present effects, and the naphthoquinones' capacities to affect mitochondrial respiration and mite growth and development is a hallmark of many acaricides available on the market, 
namely rotenone and piericidins [38,39]. In this regard, almost all shikonin derivatives isolated from O. visianii are endowed with ester groups. Once they cross the cuticle and enter mite cells, they may undergo breaking of the ester linkage, resulting in the active metabolite which is capable of inhibiting the respiration of mitochondria at Complex III in the electron transfer chain. One of the possible binding sites appeared to be the ubiquinol oxidation site $\left(\mathrm{Q}_{\mathrm{O}}\right)$ of Complex III [38].

Finally, it can be noted that the extract from the roots of $O$. visianii provided significant acaricidal efficacy due to the naphthoquinones contained in the extract. Thanks to isolation of individual compounds contained in the extract and their chemical analysis, we successfully determined the most efficient compound-isovalerylshikonin, which showed the most significant acaricidal, antiovipositional, and ovicidal effects against T. urticae. The efficacy of the extract and the selected compounds contained in the extract caused chronic mortality which manifested from day 5 after application. However, given that the $\mathrm{LD}_{90}$ for the extract as well as for isovalerylshikonin was estimated as less than $10 \mu \mathrm{g} \cdot \mathrm{cm}^{-2}$, which is approximately equivalent to the concentration of $0.1 \%$ considering the used application of $10 \mu \mathrm{L}$ of the application liquid per $1 \mathrm{~cm}^{2}$, the acaricidal efficacy of isovalerylshikonin as well as that of the extract from $O$. visianii roots can be considered sufficient for the development of new commercial acaricides.

\section{Experimentals}

\subsection{Plant Material}

Roots of O. visianii were collected in the Strážovské vrchy hills, Dolné Vestenice, Rokošské predhorie foothill, Stredná dolina valley, Trenčín Region, Slovakia $\left(48^{\circ} 44^{\prime} 01.0^{\prime \prime} \mathrm{N}, 18^{\circ} 23^{\prime} 50.8^{\prime \prime} \mathrm{E}, \mathrm{ca}\right.$. $500 \mathrm{~m}$ a.s.1.) in November 2014. Botanical identification was performed by V. Kolarčik, after checking against The Plant List database (www.theplantlist.org). A voucher specimen was deposited in the KO herbarium (Herbarium of the Botanical Garden, P. J. Šafárik University, Košice, Slovakia) with the codex DV13.

\subsection{Preparation of Extracts}

Onosma visianii roots were air-dried in the shade at room temperature $\left(\sim 25^{\circ} \mathrm{C}\right)$ for one week and conserved in wrapping papers before extraction. Dry roots were then powdered using a blender MFC DCFH 48 IKA-WERK (Staufen, Germany) equipped with sieves of $2 \mathrm{~mm}$ diameter. Eighty grams of root powder were extracted in a Soxhlet apparatus using $500 \mathrm{~mL}$ of $n$-hexane. These conditions assured the highest efficiency for extraction of naphthoquinones as reported in the literature [20]. The obtained extracts were concentrated under reduced pressure at $30{ }^{\circ} \mathrm{C}$ with a rotary evaporator up to constant weight (yield $2.7 \% w / w$ dry weight). The extract was kept in a glass vial sealed with silicon septa and stored under darkness at $-4{ }^{\circ} \mathrm{C}$ before chemical analysis and biological experiments.

\subsection{Isolation and Chemical Analyses}

Silica gel plates (cod 5171 Merck) and silica gel (60 mesh) were obtained from Sigma (Milan, Italy). Solvents were obtained from Carlo Erba (Milan, Italy). HPLC Varian 920 chromatograph (Varian, Palto Alto, CA, USA) was used for preparative chromatography. NMR (1D and 2D) spectra were obtained on a Bruker Avance 400 spectrometer (Bruker, Billerica, MA, USA). NMR spectra for compounds 8 and $\mathbf{1 1}$ can be found at Supplementary Materials. Chemical shifts $(\delta)$ are expressed in ppm. The soxhlet hexane extract of $O$. visianii root $(2.5 \mathrm{~g})$ was eluted in a silica gel column $(5 \times 30 \mathrm{~cm}, 300 \mathrm{~g}$ Silica Gel $80 \mathrm{mesh})$ using cyclohexane (A) and ethyl acetate (B) as the eluting system, starting from 100\% A and gradually increasing the B amount up to 50\%. Fractions of $12 \mathrm{~mL}$ were collected and pooled on the basis of their chromatographic behavior by TLC in 11 different fractions: fr-1 (0.68 g), fr-2 (0.43 g), fr-3 (0.31 g), fr-4 (0.09 g), fr-5 (0.08 g), fr-6 (0.08 g), fr-7 $(0.11 \mathrm{~g}), \mathrm{fr}-8(0.06 \mathrm{~g}), \mathrm{fr}-9(0.06 \mathrm{~g}), \mathrm{fr}-10(0.04 \mathrm{~g})$, and fr-11 (0.01 g). All the fractions were used for compound isolation. Further purifications were obtained with semipreparative HPLC on a Zorbax 
SB C-18 $(21.2 \times 150 \mathrm{~mm}, 5 \mu \mathrm{m})$ column using as mobile phase methanol and water $(0.1 \%$ formic acid) in isocratic elution (90:10) for $25 \mathrm{~min}$. The flow rate was $5 \mathrm{~mL} / \mathrm{min}$. UV detection was used at 545 and $254 \mathrm{~nm}$. The purity of the isolated compounds was checked by HPLC analysis and was $>97 \%$ by software integration. Quantification of the shikonin derivatives in the crude extract was performed using ${ }^{1} \mathrm{H}-\mathrm{NMR}$ as previously described. Briefly, $50 \mathrm{mg}$ of crude extracts were exactly weighed and dissolved in a deuterated chloroform solution of caffeine $(1 \mathrm{mg} / \mathrm{mL})$. Peaks were assigned to the methyl groups of caffeine ( $\delta 3.43)$ and clearly resolved peaks assigned to the $\mathrm{H}-3$ of shikonin derivatives $(\delta 7.00)$ were then used for quantitative analysis using a previously published approach [40]. Isolated compounds were isovalerylshikonin $\mathbf{1}(37.2 \mathrm{mg})$, isobutyrylshikonin 2 (63.2 $\mathrm{mg})$, acetylshikonin 3 (16.6 mg), hydroxyisovalerylshikonin 4 (2.4 mg), shikonin- $\beta, \beta$-dimethylacrylate 5 $(58.7 \mathrm{mg})$, propionylshikonin 6 (1.1 mg), 5,8 dimethoxy acetylshikonin 7 (8.1 mg), 1-(5,8-dimethoxy1,4-dioxo-1,4-dihydronaphthalen-2-yl)-4-methylpent-3-en-1-yl 2-methylbutanoate 8 (0.8 mg), 5,8 dimethoxy isobutyrylshikonin $9(0.6 \mathrm{mg})$, 5,8-O-dimethyldeoxyshikonin 10 (4 mg), and (E)-2-(4hydroxy-4-methylpent-2-en-1-yl)-5,8-dimethoxynaphthalene-1,4-dione 11 (0.5 mg). The structures of the compounds were elucidated on the basis of $1 \mathrm{D}$ and 2D NMR measurements, comparing obtained data with previously published literature [41-44].

\subsection{Mite Rearing}

Two-spotted spider mites, T. urticae Koch (Acari: Tetranychidae), were obtained from the cultures maintained at the Crop Research Institute (Prague, Czech Republic). The spider mites used in the experiments were reared on bean plants (Phaseolus vulgaris L. var. Carmen) in a growth chamber (22-25 ${ }^{\circ} \mathrm{C}$; a $12 \mathrm{~h}$ photoperiod).

\subsection{Tarsal Toxicity Tests}

The method of Pavela [45] was used to determine the acaricidal efficacy of the extract from O. visianii. The tarsal test was used to determine the extract efficacy in terms of mortality of T. urticae adults after $24 \mathrm{~h}$ (considered as acute toxicity) and at 5 days (considered as chronic toxicity) from application. The experiment was done in bean plants ( $P$. vulgaris var. Carmen) with discs sized $2 \mathrm{~cm}^{-2}$. First, stock solutions of the extract were prepared by dissolving an appropriate amount of the extract in methanol to obtain the concentration series of $1.5 \%, 1.0 \%, 0.8 \%, 0.5 \%, 0.3 \%, 0.2 \%, 0.1 \%, 0.05 \%, 0.02 \%$, and $0.01 \%(w / v)$. An automatic pipette was used to uniformly apply $20 \mu \mathrm{L}$ of the solution on one side of the disc $\left(10 \mu \mathrm{L} \cdot \mathrm{cm}^{-2}\right)$. A concentration series was thereby obtained, equivalent to the doses of $150,100,80,50,30,20,10,5,2$, and $1 \mu \mathrm{g} \cdot \mathrm{cm}^{-2}$. Only methanol was applied to the control discs. After application, the discs were placed in Petri dishes $(5 \mathrm{~cm}$ in diameter) with an agar layer $0.3 \mathrm{~cm}$ thick on the bottom (to maintain the freshness of the discs and standard ambient humidity).

After evaporation of the solvent (approximately $10 \mathrm{~min}$ from application), a fine brush was used to transfer 10 females of T. urticae (2-3 days old) on each of the treated sides of the leaf discs. The Petri dishes were placed in a growth chamber (L16:D8, $25^{\circ} \mathrm{C}$ ). The cut leaf discs were checked after $24 \mathrm{~h}$ and 5 th day after application, determining the number of dead adults using binoculars. Death was recorded when the larvae did not respond to prodding with forceps. The determined mortality was used to estimate the lethal doses causing 50\% (90\%) mortality of T. urticae. The experiment was repeated 5 times.

\subsection{Effect on Oviposition}

The same method as above was used to prepare bean discs treated with the extract. Five adults (3-4 days old) were transferred using a fine brush on each of the cut bean leaf discs. The cut discs with the adults were placed in Petri dishes with an agar bottom. The Petri discs were placed in a growth chamber (L16:D8, $25^{\circ} \mathrm{C}$ ). After $24 \mathrm{~h}$, the laid eggs were counted. For female mortality, the number of oviposited eggs was recalculated to live females. The determined number of eggs oviposited by 
females was used to calculate the percent inhibition of oviposition and to estimate lethal doses causing $50 \%(90 \%)$ inhibition of oviposition compared to the control. The experiment was repeated 5 times.

\subsection{Acaricidal and Antiovipositional Effect of Compounds Isolated from the Extract}

The same method as above, with minor modifications, was used to determine mortality and antioviposition. In order to determine the most active compounds, all 11 compounds were first tested only in the dose of $15 \mu \mathrm{g} \cdot \mathrm{cm}^{-2}$. Each time, 10 adults (2-3 days old) or 20 nymphs ( 5 days old) were transferred to the treated discs using a fine brush. Mortality of T. urticae adults and nymphs was assessed on days 2 and 5 from application. The same method as above was used to determine the inhibition of oviposition for days 2 and 5 from application. For compounds showing $100 \%$ mortality on day 5 from application, a series of different doses $\left(13.5,6.8,3.4,1.7\right.$, and $\left.0.8 \mu \mathrm{g} \cdot \mathrm{cm}^{-2}\right)$ was used to determine lethal doses causing $50 \%(90 \%)$ mortality or inhibition of oviposition.

\subsection{Ovicidal Effect}

Using a fine brush, we transferred five adults (3-4 days old) onto each $1 \mathrm{~cm}^{-2}$ cut bean leaf disc. We placed the cut discs with the adults into Petri dishes having an agar bottom. After $24 \mathrm{~h}$, the adults were taken out and the eggs that had been laid were counted. We left the eggs for $24 \mathrm{~h}$ more; then, we used an automatic pipette to uniformly apply $10 \mu \mathrm{L}$ of methanol containing a specified dissolved amount of the compounds to the cut pieces, so that the concentration series equaled doses of 13.5, $6.8,3.4,1.7$, and $0.8 \mu \mathrm{g} \cdot \mathrm{cm}^{-2}$. We applied pure methanol to the control discs, which were placed in Petri dishes following application. The Petri dishes were $5 \mathrm{~cm}$ in diameter, with an agar layer $0.3 \mathrm{~cm}$ thick on the bottom to maintain the freshness of the cut pieces and a standard ambient humidity. We checked the eggs every day for 10 days and recorded the emerged nymphs, which were subsequently removed. Ovicidal efficacy was calculated using the number of eggs that had not emerged 10 days after application. The Petri dishes were put into a growth chamber $\left(\mathrm{L} 16: \mathrm{D} 8,25^{\circ} \mathrm{C}\right)$. We repeated the experiment 5 times.

\subsection{Statistical Analysis}

Experimental testing confirmed that over $20 \%$ of the controlled mortality was discharged and repeated. The observed mortality was corrected by Abbott's formula [46] after the controlled mortality reached $1-20 \%$. The $\mathrm{LD}_{50}$ and $\mathrm{LD}_{90}$ values and associated $95 \%$ confidence limits for each treatment were estimated using probit analysis of dose-mortality data [47].

The following formula was used to determine the inhibition of oviposition (IO):

$$
\mathrm{IO}(\%)=((\mathrm{Co}-\mathrm{To}) / \mathrm{Co}) \times 100
$$

where To $=$ number of eggs $/$ female in the treated disc, and Co $=$ number of eggs $/$ female in the control disc.

\section{Conclusions}

The present work provided new scientific evidences for the industrial exploitation of naphthoquinones belonging to the shikonin family. In particular, these lipophilic pigments, easily obtainable from the roots of several Boraginaceae species, are promising candidate ingredients to be incorporated in acaricidal products to be used in crop protection.

Supplementary Materials: Supplementary Materials are available online.

Acknowledgments: R. Pavela would like to thank the Ministry of Agriculture of the Czech Republic for its financial support concerning botanical pesticide research (Project No. MZE RO0417). F. Maggi acknowledges the University of Camerino (Fondo di Ateneo per la Ricerca, FAR 2014/2015 FPI000044) for financial support. 
Author Contributions: S.S., F.M., G.B., R.Pavela, S.D., V.K.: experiment design and supervision of all experiments and results. S.S., S.D., G.B., F.M., L.C., R.Petrelli: analysis of the results and manuscript preparation. All authors read and approved the final manuscript.

Conflicts of Interest: Authors declare they have not any conflict of interest.

\section{References}

1. Naqqash, M.N.; Gökçe, A.; Bakhsh, A.; Salim, M. Insecticide Resistance and its Molecular Basis in Urban Insect Pests. Parasitol. Res. 2016, 115, 1363-1373. [CrossRef] [PubMed]

2. Benelli, G.; Pavela, R.; Maggi, F.; Petrelli, R.; Nicoletti, M. Commentary: Making Green Pesticides Greener? The Potential of Plant Products for Nanosynthesis and Pest Control. J. Clust. Sci. 2017, 28, 3-10. [CrossRef]

3. Pavela, R. History, Presence and Perspective of using Plant Extracts as Commercial Botanical Insecticides and Farm Products for Protection Against Insects-A Review. Plant Prot. Sci. 2016, 52, $229-241$.

4. Pavela, R.; Benelli, G. Ethnobotanical Knowledge on Botanical Repellents Employed in the African Region against Mosquito Vectors-A Review. Exp. Parasitol. 2016, 167, 103-108. [CrossRef] [PubMed]

5. Pavela, R.; Benelli, G. Essential Oils as Ecofriendly Biopesticides? Challenges and Constraints. Trends Plant Sci. 2016, 21, 1000-1007. [CrossRef] [PubMed]

6. Benelli, G.; Pavela, R.; Canale, A.; Nicoletti, M.; Petrelli, R.; Cappellacci, L.; Galassi, R.; Maggi, F. Isofuranodiene and Germacrone from Smyrnium olusatrum Essential Oil as Acaricides and Oviposition Inhibitors Against Tetranychus urticae: Impact of Chemical Stabilization of Isofuranodiene by Interaction with Silver Triflate. J. Pest Sci. 2017, 90, 693-699. [CrossRef]

7. Zhang, Z. Mites of Greenhouses: Identification, Biology and Control; CABI Publishing: Cambridge, UK, 2003.

8. Van Leeuwen, T.; Vontas, J.; Tsagkarakou, A.; Dermauw, W.; Tirry, L. Acaricide Resistance Mechanisms in the Two-Spotted Spider Mite Tetranychus urticae and Other Important Acari: A Review. Insect Biochem. Mol. Biol. 2010, 40, 563-572. [CrossRef] [PubMed]

9. Kwon, D.H.; Clark, J.M.; Lee, S.H. Toxicodynamic Mechanisms and Monitoring of Acaricide Resistance in the Two-Spotted Spider Mite. Pestic. Biochem. Physiol. 2015, 121, 97-101. [CrossRef] [PubMed]

10. Strid, A.; Tan, K. Mountain Flora of Greece; Edinburgh University Press: Edinburgh, UK, 1991.

11. Tutin, T.G. Flora Europea; Cambridge University Press: Cambridge, UK, 1964.

12. Tosun, A.; Akkol, E.K.; Bahadir, O.; Yesilada, E. Evaluation of Anti-Inflammatory and Antinociceptive Activities of some Onosma L. Species Growing in Turkey. J. Ethnopharmacol. 2008, 120, 378-381. [CrossRef] [PubMed]

13. Papageorgiou, V.P.; Assimopoulou, A.N.; Couladouros, E.A.; Hepworth, D.; Nicolaou, K.C. The Chemistry and Biology of Alkannin, Shikonin, and Related Naphthazarin Natural Products. Angew. Chem. Int. Ed. 1999, 38, 270-300. [CrossRef]

14. Kumar, N.; Kumar, R.; Kishore, K. Onosma L.: A Review of Phytochemistry and Ethnopharmacology. Pharmacogn. Rev. 2013, 7, 140-151. [CrossRef] [PubMed]

15. Dong, M.; Liu, D.; Li, Y.; Chen, X.; Luo, K.; Zhang, Y.; Li, R. Naphthoquinones from Onosma paniculatum with Potential Anti-Inflammatory Activity. Planta Med. 2017, 83, 631-635. [CrossRef] [PubMed]

16. Nikita, G.; Vivek, P.; Chhaya, G. Wound-Healing Activity of an Oligomer of alkannin/shikonin, Isolated from Root Bark of Onosma echioides. Nat. Prod. Res. 2015, 29, 1584-1588. [CrossRef] [PubMed]

17. Vukic, M.D.; Vukovic, N.L.; Djelic, G.T.; Popovic, S.L.; Zaric, M.M.; Baskic, D.D.; Krstic, G.B.; Tesevic, V.V.; Kacaniova, M.M. Antibacterial and Cytotoxic Activities of Naphthoquinone Pigments from Onosma visianii Clem. EXCLI J. 2017, 16, 73-88. [PubMed]

18. Babula, P.; Adam, V.; Kizek, R.; Sladký, Z.; Havel, L. Naphthoquinones as Allelochemical Triggers of Programmed Cell Death. Environ. Exp. Bot. 2009, 65, 330-337. [CrossRef]

19. Akhtar, Y.; Isman, M.B.; Niehaus, L.A.; Lee, C.; Lee, H. Antifeedant and Toxic Effects of Naturally Occurring and Synthetic Quinones to the Cabbage Looper, Trichoplusia ni. Crop Prot. 2012, 31, 8-14. [CrossRef]

20. Babula, P.; Adam, V.; Havel, L.; Kizek, R. Noteworthy Secondary Metabolites Naphthoquinones-Their Occurrence, Pharmacological Properties and Analysis. Curr. Pharm. Anal. 2009, 5, 47-68. [CrossRef]

21. Lubbe, A.; Verpoorte, R. Cultivation of Medicinal and Aromatic Plants for Specialty Industrial Materials. Ind. Crops Prod. 2011, 34, 785-801. [CrossRef] 
22. Malik, S.; Bhushan, S.; Sharma, M.; Ahuja, P.S. Biotechnological Approaches to the Production of Shikonins: A Critical Review with Recent Updates. Crit. Rev. Biotechnol. 2016, 36, 327-340. [CrossRef] [PubMed]

23. Lee, C.; Lee, H. Acaricidal Activity and Function of Mite Indicator using Plumbagin and its Derivatives Isolated from Diospyros kaki Thunb. Roots (Ebenaceae). J. Microbiol. Biotechnol. 2008, 18, 314-321. [PubMed]

24. Akhtar, Y.; Isman, M.B.; Lee, C.-H.; Lee, S.-G.; Lee, H.-S. Toxicity of Quinones against Two-Spotted Spider Mite and Three Species of Aphids in Laboratory and Greenhouse Conditions. Ind. Crops Prod. 2012, 37, 536-541. [CrossRef]

25. Tokunaga, T.; Dohmura, A.; Takada, N.; Ueda, M. Cytotoxic Antifeedant from Dionaea muscipula Ellis: A Defensive Mechanism of Carnivorous Plants against Predators. Bull. Chem. Soc. Jpn. 2004, 77, 537-541. [CrossRef]

26. Khambay, B.P.S.; Batty, D.; Jewess, P.J.; Bateman, G.L.; Hollomon, D.W. Mode of Action and Pesticidal Activity of the Natural Product Dunnione and of some Analogues. Pest Manag. Sci. 2003, 59, 174-182. [CrossRef] [PubMed]

27. Hari Babu, T.; Rama Subba Rao, V.; Tiwari, A.K.; Suresh Babu, K.; Srinivas, P.V.; Ali, A.Z.; Madhusudana Rao, J. Synthesis and Biological Evaluation of Novel 8-Aminomethylated Oroxylin A Analogues as $\alpha$-Glucosidase Inhibitors. Bioorg. Med. Chem. Lett. 2008, 18, 1659-1662. [CrossRef] [PubMed]

28. Cespedes, C.L.; Lina-Garcia, L.; Kubo, I.; Salazar, J.R.; Ariza-Castolo, A.; Alarcon, J.; Aqueveque, P.; Werner, E.; Seigler, D.S. Calceolaria Integrifolia s.l. Complex, Reduces Feeding and Growth of Acanthoscelides Obtectus, and Epilachna varivestis. A New Source of Bioactive Compounds against Dry Bean Pests. Ind. Crops Prod. 2016, 89, 257-267. [CrossRef]

29. Michaelakis, A.; Strongilos, A.T.; Bouzas, E.A.; Koliopoulos, G.; Couladouros, E.A. Larvicidal Activity of Naturally Occurring Naphthoquinones and Derivatives against the West Nile Virus Vector Culex pipiens. Parasitol. Res. 2009, 104, 657-662. [CrossRef] [PubMed]

30. Khambay, B.P.S.; Batty, D.; Beddie, D.G.; Denholm, I.; Cahill, M.R. A New Group of Plant-Derived Naphthoquinone Pesticides. Pestic. Sci. 1997, 50, 291-296. [CrossRef]

31. Pavela, R. Efficacy of Naphthoquinones as Insecticides against the House Fly, Musca domestica L. Ind. Crops Prod. 2013, 43, 745-750. [CrossRef]

32. Wakasa, F.; Watanabe, S. Kanemite (Acequinocyl, AKD-2023) -A New Acaricide for Control of various Species of Mites. Agrochem. Jpn. 2000, 17-20.

33. Dekeyser, M.A. Acaricide Mode of Action. Pest Manag. Sci. 2005, 61, 103-110. [CrossRef] [PubMed]

34. Meazza, G.; Dayan, F.E.; Wedge, D.E. Activity of Quinones on Colletotrichum Species. J. Agric. Food Chem. 2003, 51, 3824-3828. [CrossRef] [PubMed]

35. Vennerstrom, J.L.; Eaton, J.W. Oxidants, Oxidant Drugs, and Malaria. J. Med. Chem. 1988, 31, $1269-1277$. [CrossRef] [PubMed]

36. Ferraz, P.A.L.; De Abreu, F.C.; Pinto, A.V.; Glezer, V.; Tonholo, J.; Goulart, M.O.F. Electrochemical Aspects of the Reduction of Biologically Active 2-Hydroxy-3-Alkyl-1,4-Naphthoquinones. J. Electroanal. Chem. 2001, 507, 275-286. [CrossRef]

37. Monks, T.J.; Hanzlik, R.P.; Cohen, G.M.; Ross, D.; Graham, D.G. Quinone Chemistry and Toxicity. Toxicol. Appl. Pharmacol. 1992, 112, 2-16. [CrossRef]

38. Koura, Y.; Kinoshita, S.; Takasuka, K.; Koura, S.; Osaki, N.; Matsumoto, S.; Miyoshi, H. Respiratory Inhibition of Acaricide AKD-2023 and its Deacetyl Metabolite. J. Pestic. Sci. 1998, 23, 18-21. [CrossRef]

39. Nauen, R.; Bretschneider, T. New Modes of Action of Insecticides. Pestic. Outlook 2002, 13, 241-245. [CrossRef]

40. Comai, S.; Dall'Acqua, S.; Grillo, A.; Castagliuolo, I.; Gurung, K.; Innocenti, G. Essential Oil of Lindera neesiana Fruit: Chemical Analysis and its Potential use in Topical Applications. Fitoterapia 2010, 81, 11-16. [CrossRef] [PubMed]

41. Chaouche, T.; Haddouchi, F.; Bekkara, F.A. Identification of Shikonin from the Roots of Echium Pycnanthum Pomel. Asian J. Pharm. Clin. Res. 2012, 5, 30-32.

42. Ito, Y.; Onobori, K.; Yamazaki, T.; Kawamura, Y. Tigloylshikonin, a New Minor Shikonin Derivative, from the Roots and the Commercial Root Extract of Lithospermum Erythrorhizon. Chem. Pharm. Bull. 2011, 59, 117-119. [CrossRef] [PubMed]

43. Kim, J.Y.; Jeong, H.J.; Park, J.Y.; Kim, Y.M.; Park, S.J.; Cho, J.K.; Park, K.H.; Ryu, Y.B.; Lee, W.S. Selective and Slow-Binding Inhibition of Shikonin Derivatives Isolated from Lithospermum Erythrorhizon on Glycosyl Hydrolase 33 and 34 Sialidases. Bioorg. Med. Chem. 2012, 20, 1740-1748. [CrossRef] [PubMed] 
44. Spyros, A.; Assimopoulou, A.N.; Papageorgiou, V.P. Structure Determination of Oligomeric Alkannin and Shikonin Derivatives. Biomed. Chromatogr. 2005, 19, 498-505. [CrossRef] [PubMed]

45. Pavela, R. Acaricidal Properties of Extracts and Major Furanochromenes from the Seeds of Ammi visnaga Linn. against Tetranychus urticae Koch. Ind. Crops Prod. 2015, 67, 108-113. [CrossRef]

46. Abbott, W.S. A Method of Computing the Effectiveness of an Insecticide. 1925. J. Am. Mosq. Control Assoc. 1987, 3, 302-303. [PubMed]

47. Finney, D. Probit Analysis; Cambridge University Press: London, UK, 1971.

Sample Availability: Samples of the compounds are available from the authors.

(C) 2017 by the authors. Licensee MDPI, Basel, Switzerland. This article is an open access article distributed under the terms and conditions of the Creative Commons Attribution (CC BY) license (http:/ / creativecommons.org/licenses/by/4.0/). 